\title{
Crayfish distribution updating in central Italy
}

\author{
M. Scalici ${ }^{(1)}$, M. Pitzalis ${ }^{(1)}$, G. Gibertini $i^{(1)}$ \\ Received September 29, 2009 / Reçu le 29 septembre 2009 \\ Revised November 18, 2009 / Révisé le 18 novembre 2009 \\ Accepted November 23, 2009 / Accepté le 23 novembre 2009
}

Key-words: crayfish distribution, white-clawed crayfish, non indigenous crayfish species, geographic information system, central Italy

\section{ABSTRACT}

Introductions of non-indigenous crayfish have received great attention from biologists and policy makers during the last decade. Purposes of this study are to update the knowledge about the crayfish distribution in Latium (central Italy), and to show how interactions between indigenous and non-indigenous species can affect their distribution. The main findings of this study were (1) the great decrease of the Austropotamobius pallipes populations and (2) the alarming spread of the four non-indigenous species red swamp crayfish Procambarus clarkii (the main widespread crayfish), spiny-cheek crayfish Orconectes limosus, narrow-clawed crayfish Astacus leptodactylus, and yabby Cherax destructor. We never observed indigenous and non-indigenous crayfish living in syntopy, although we noted that white-clawed crayfish had become extinct at sites where non-indigenous crayfish species exist now. Other type of problems (i.e. illegal harvesting and over-abstraction of water for human use) can also reduce the distribution and abundance of the indigenous crayfish stocks. The distribution of Italian crayfish populations has not been studied sufficiently and more studies are required nationwide to assess the conservation status of $A$. pallipes and the occurrence of non-indigenous species. A national database of crayfish records ought to be constructed and regularly updated.

\section{RÉSUMÉ}

\section{Actualisation de la distribution des écrevisses en Italie centrale}

Mots-clés : distribution des écrevisses, écrevisse à pattes blanches, espèces d'écrevisses non-indigènes, système d'information géographique, Italie centrale
Les introductions d'écrevisses non-indigènes ont reçu une grande attention des biologistes et des gestionnaires durant les dernières décennies. Les objectifs de cette étude sont de mettre à jour les connaissances sur la distribution des écrevisses dans le Latium (Italie centrale) et de montrer comment les interactions entre les espèces indigènes et non-indigènes peuvent affecter leur distribution. Les principaux résultats de cette étude sont (1) la forte décroissance des populations d'Austropotamobius pallipes et (2) l'alarmante dispersion de quatre espèces non-indigènes, l'écrevisse de Louisiane Procambarus clarkii (l'espèce la plus répandue), l'écrevisse américaine Orconectes limosus, l'écrevisse à pieds grêles Astacus leptodactylus et l'écrevisse de Murray Cherax destructor. Nous n'avons jamais observé d'écrevisses indigènes et non-indigènes vivant en sympatrie, bien que nous ayons noté que l'écrevisse à pattes blanches a disparu dans les sites où des espèces non-indigènes existent maintenant. D'autres types de causes (i.e. pêche illégale et surexploitation pour la consommation humaine) peuvent

(1) Dipartimento di Biologia, Università degli Studi "Roma Tre”, v.le G. Marconi 446, 00146 Roma, Italy, scalici@uniroma3.it 
aussi réduire la distribution et l'abondance des populations d'écrevisses indigènes. La distribution des populations d'écrevisses italiennes n'a pas été suffisamment étudiée et des études à l'échelle nationale sont nécessaires pour assurer le statut de conservation d'A. pallipes et l'occurrence des espèces nonindigènes. Une base de données nationale des localisations d'écrevisses devrait être construite et régulièrement actualisée.

\section{INTRODUCTION}

Introductions of non-indigenous crayfish (NICs) have received a lot of attention from biologists and policy makers (Lodge et al., 2000). In Italy several non-native crayfish have been recorded (Souty-Grosset et al., 2006; Capurro et al., 2007; Gherardi et al., 2008b): (a) three American species, the red-swamp crayfish Procambarus clarkii (Girard, 1852), the spiny-cheek crayfish Orconectes limosus (Rafinesque, 1817), and the signal crayfish Pacifastacus leniuscuIus (Dana, 1852); (b) two Australian species, the yabby Cherax destructor (Clark, 1936), and the redclaw C. quadricarinatus (von Martens, 1868); (c) one eastern European species, the narrow-clawed crayfish Astacus leptodactylus (Eschscholtz, 1823). C. quadricarinatus was only observed in rearing systems (Gherardi et al., 1999), whilst C. destructor was recently recorded in abandoned outdoor ponds within the protected area "Laghi di Ninfa" (Latina, Latium) (Scalici et al., 2009a). Then, in central Italy four NICs occur: P. clarkii, O. limosus, A. leptodactylus (see Chiesa et al., 2006), and C. destructor (Scalici et al., 2009a). On the whole, NICs show a wide distribution due to their ability to adapt to a wide range of habitat and food sources, especially P. clarkii (Gherardi, 2006; Scalici et al., 2009b).

During the three last decades we have observed a drastic decrease of the indigenous whiteclawed crayfish Austropotamobius pallipes (Lereboullet, 1858), which is currently listed as vulnerable by the IUCN, and is included in Appendix III of the Bern Convention and in Annex II and $V$ of the Directive 92/43/ECC. It is also protected in the Latium region of Italy by the regional law $n^{\circ} 88 / 18$, which forbids catch, transport and sale.

A useful starting point for developing a management strategy to conserve the decreasing populations of white-clawed crayfish is a detailed characterization of the geographic range of the species and the factors affecting its distribution. This information is needed to address three interlinked problems: (1) conserving indigenous populations; (2) preventing the spread of exotic species; (3) preventing the spread of pathogen agents, with particular reference to Aphanomyces astaci Schikora, 1922, which causes the lethal disease of aphanomycosis, or crayfish plague, in all the European species of crayfish and is one of the main causes of local extinction of populations of the European crayfish (Gherardi and Holdich, 1999).

Although data on crayfish occurrence were recently collected in Europe (Souty-Grosset et al., 2006), detailed studies on the occurence of indigenous and exotic crayfish at national scale are missing in Italy, and only a few detailed provincial studies have been carried out to date (for a short review on this topic, see Scalici et al., 2006, and Gherardi et al., 2008a).

The purpose of this study is to improve the knowledge of the historic and current distribution of indigenous and exotic crayfish in Latium and to use this in a geographic information system (GIS) to help identify the threats to indigenous populations and to predict future distributions of the various crayfish species.

\section{MATERIALS AND METHODS}

We summarized data collected in field within different monitoring projects on crayfish, invertebrates, fish, amphibians during a period of eight years (2001-2008) in Latium (Figure 1) and combined our recent records on the crayfish distribution with previous known literature (Vinciguerra, 1898, and Mancini, 1986 for A. pallipes), and personal communications of river anglers, Italian Forestry Corps and local authorities. Collected data have been geo-referenced 


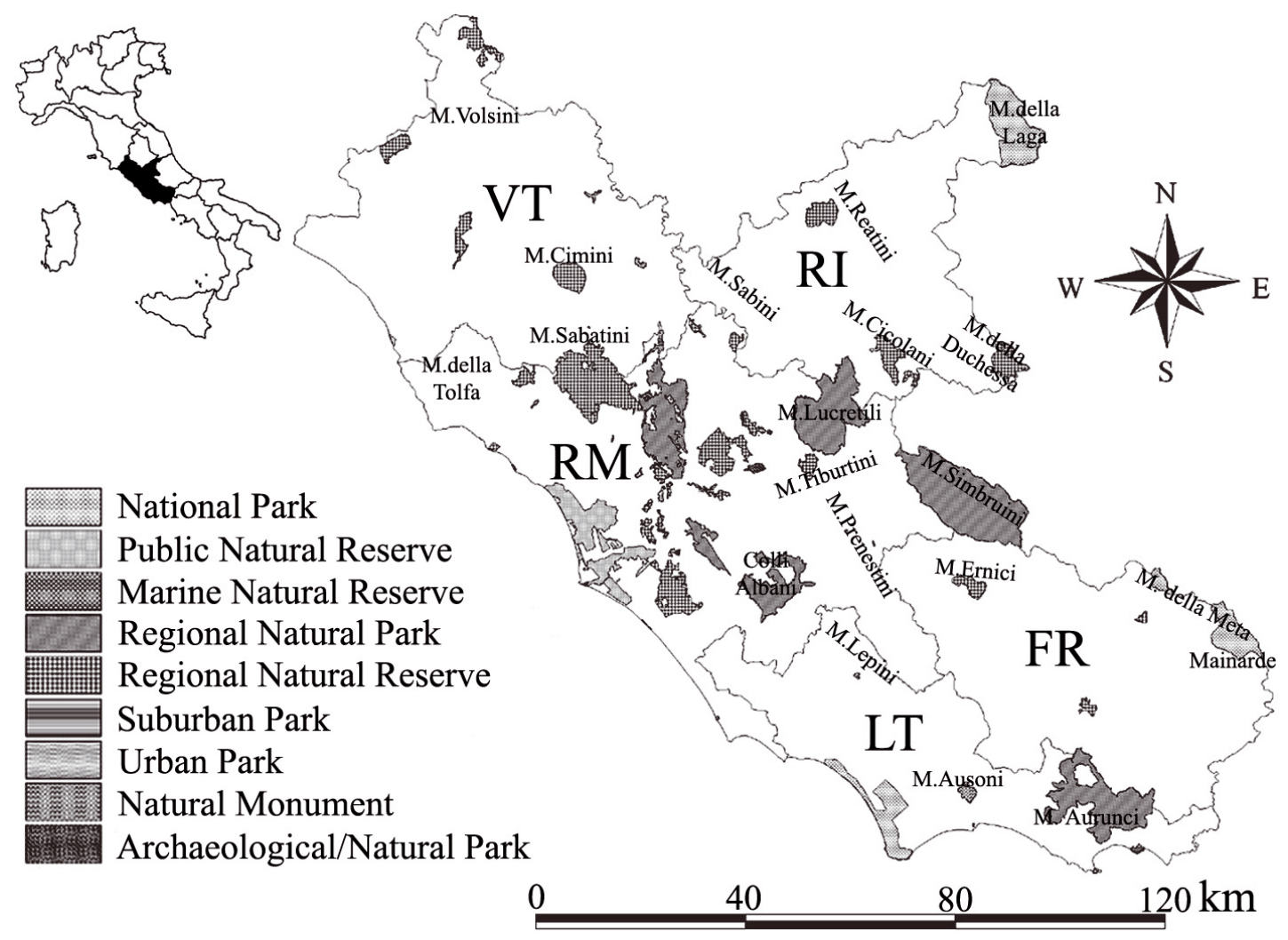

\section{Figure 1}

Preserved areas and main mountain ranges of Latium, the latter divided in five provinces (from north to south): $V T$ = Viterbo; $R I=$ Rieti; $R M=$ Roma; $F R=$ Frosinone; $L T=$ Latina.

\section{Figure 1}

Aires de protection et principales montagnes du Latium, ce dernier étant divisé en cinq provinces (du nord au sud) $: \mathrm{VT}=$ Viterbo; RI = Rieti ; RM = Rome; FR = Frosinone; LT = Latina.

and registered in a database, to build a GIS. Data on crayfish were organized following the UTM grid $(10 \mathrm{~km} \times 10 \mathrm{~km})$ and were mapped using GIS software in order to (1) visualize the actual $A$. pallipes distribution, (2) compare the latter with the potential one (i.e. the sum of historical and recent data), and (3) describe the NICs occurrence.

\section{RESULTS}

In total 219 sites were surveyed and overall 82 (37.4\%) harboured either indigenous or indigenous-native crayfish (ICs and NICs, respectively). Among these, $A$. pallipes actually inhabited $45(53.5 \%)$ watercourses, whilst NICs were in 40 (46.5\%) sites, the latter being both still waters and slow-flowing watercourses.

The white-clawed crayfish occurred in $13(29.5 \%)$ of the investigated sites in Viterbo, $10(22.7 \%)$ in Rieti, 14 (31.8\%) in Rome, 5 (11.4\%) in Frosinone, and 2 (4.6\%) in Latina. Moreover, only $11(25.0 \%)$ of the native crayfish populations occurred within protected areas. In Figure 2 the native crayfish distribution was also compared (i.e. geographically overlapped) to altitudinal ranges. In particular, $A$. pallipes is restricted to a particular range, from $219 \mathrm{~m}$ a.s.I. to 953, within isolated areas. Finally, potential (84 sites) and actual (45) distributions of the native populations were showed in Figure 3.

$\mathrm{NICs}$ occurred in all the provinces, in 40 sites as follows: P. clarkii in 30 sites; $O$. limosus in 4; A. leptodactylus in $5 ; C$. destructor in 1 . Exotic crayfish appeared to live in syntopy only in four 


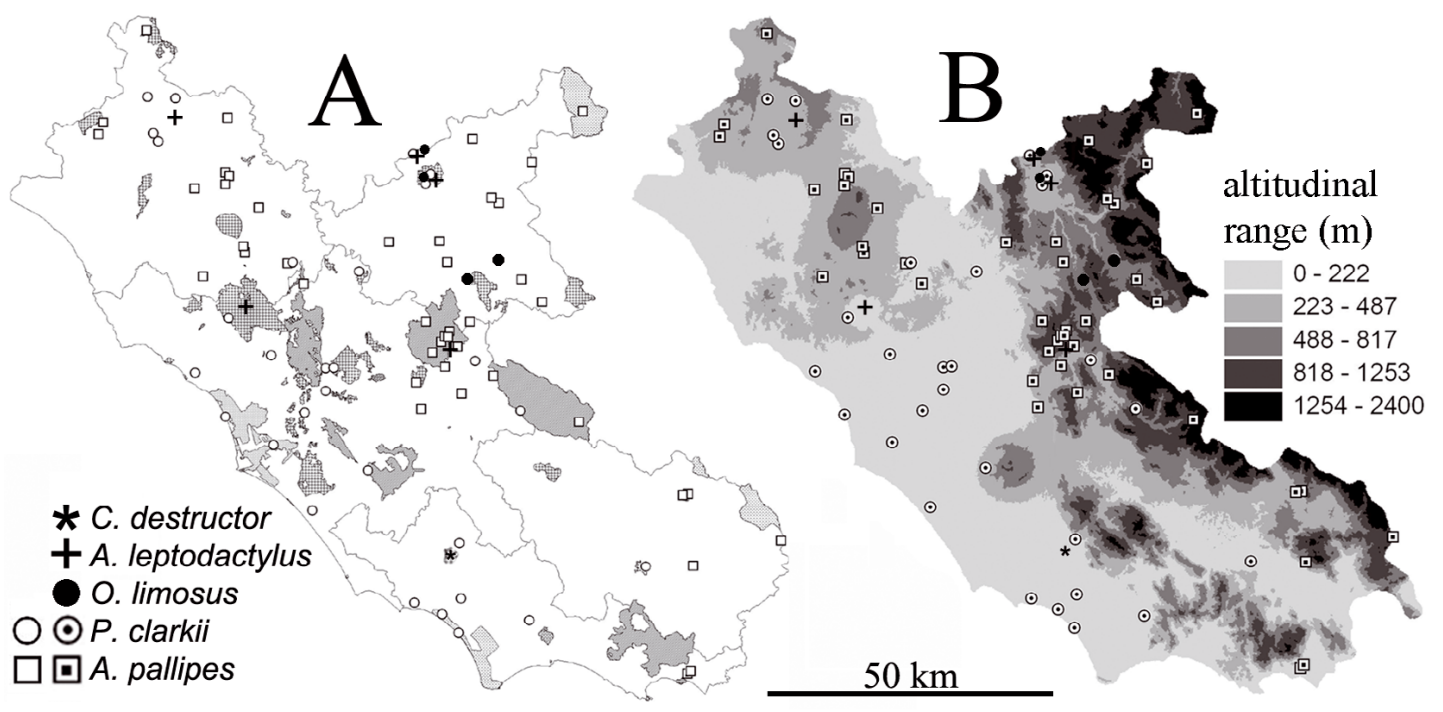

Figure 2

Occurrence of native and exotic crayfish within preserved areas $(A)$ and overlapped to the altitude (B).

Figure 2

Occurrence des écrevisses natives et exotiques dans les aires de protection $(A)$ et répartition en altitude (B).

cases: (1) P. clarkii and A. leptodactylus occurred both in Lake Bolsena (Viterbo) and within the Regional Park of Lake Bracciano (Roma); (2) P. clarkii, O. limosus and A. leptodactylus occurred in the Partial Natural Reserve of Lakes Lungo (Rieti) and Ripasottile and in Lake Piediluco (between the provinces of Terni and Rieti - in Umbria and Latium, respectively). A total of 18 records were within protected areas (44.7\%), 12 for $P$. clarkii, 2 for O. limosus, 3 for $A$. leptodactylus, and 1 for $C$. destructor (Figure 2).

\section{DISCUSSION}

Two main results emerged in this study: the drastic decrease of the native crayfish populations, overall within the provinces of Viterbo and Rieti, and the alarming widespreading of NICs, with particular references to the red swamp crayfish P. clarkii which colonized also the brackish wetland within the preserved Mediterranean biotope "Palude di Torre Flavia" (Rome) (Scalici et al., 2009b).

As for $A$. pallipes, the remaining indigenous populations occur today only sparsely within the central inland area of Latium, with the exception of two new records in Latina province (probably results of recent human introductions). Differently, among NICs O. limosus, A. leptodactylus, and $C$. destructor had, on the whole, a low number of records, while P. clarkii was the most widespread species in all the regional territory, probably due to its commercial importance for aquaculture purposes (Huner, 2002). Because of the potential economic value of commercial harvesting of $P$. clarkii there is a risk that more introductions will be made in future, in addition to the natural expansion of existing populations. But unfortunately, there are no official data concerning transport and introduction activities. We only collected informations from local fishermen and inhabitants, and this make hard to reconstruct the pattern of invasion by NICs.

The low number of populations of white clawed crayfish and the high number of NICs populations within protected areas is worrying. Some of the protected areas were set up within the past ten years, when NICs were already widely distributed in the Province of Rome, where 


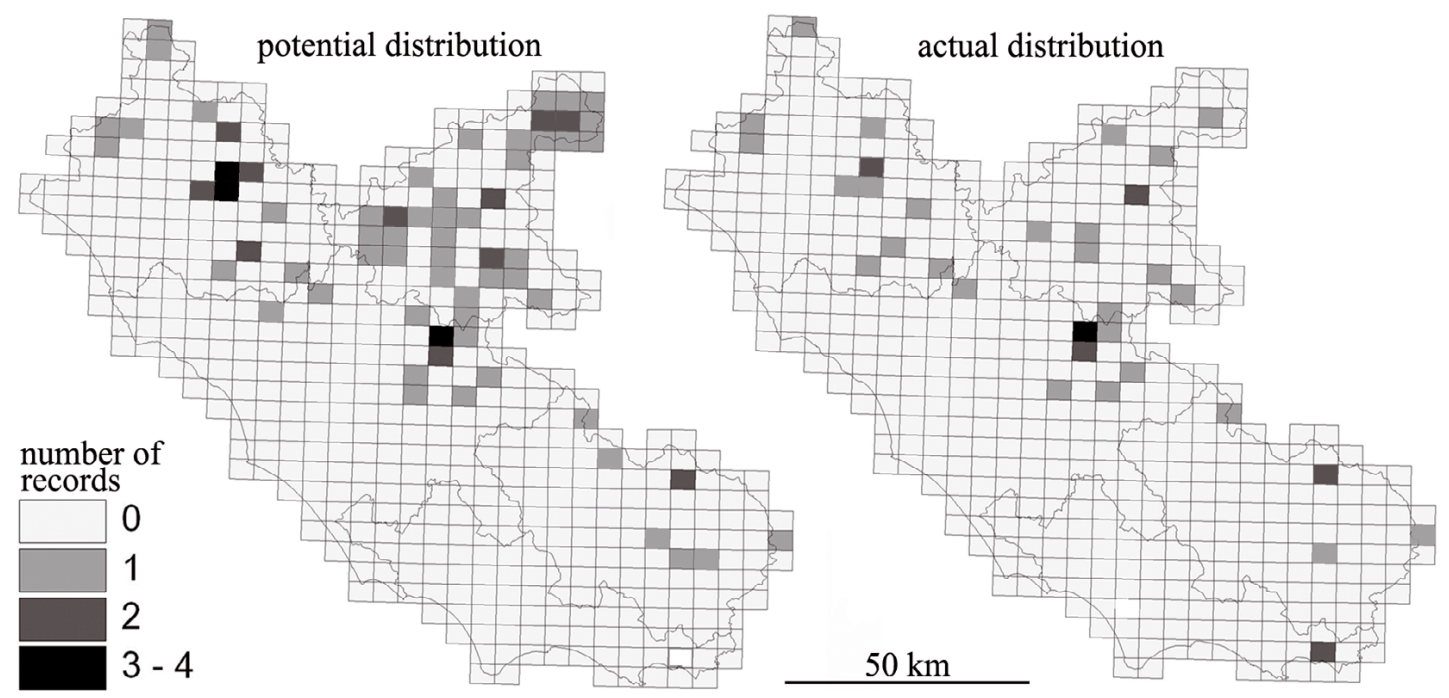

Figure 3

Number of records per each square $(5 \times 5 \mathrm{~km})$ of the potential and actual distribution of the white-clawed crayfish Austropotamobius pallipes.

Figure 3

Nombre de localisations par quadrat $(5 \times 5 \mathrm{~km})$ de la distribution potentielle et réelle de l'écrevisse à pattes blanches Austropotamobius pallipes.

alien species are widely distributed. The Monti Lucretili Regional Park (Rome) represents the main exception, being an area with native populations at high density (Scalici and Gibertini, 2005) and for this reason it seems a core to safe in terms of ex and in situ conservation, although today the risks of NICS and plague were not assessed for these populations. The other areas do not include many indigenous populations and do not contribute to their protection, making $A$. pallipes highly vulnerable to human activities, such as pollution, captation, river bed rectification, riparian vegetation mowing. Particular attention should be given to the Frosinone province, where P. clarkii was recorded within the Lake Fibreno (Chiesa et al., 2008), which is inhabited by the endemic trout Salmo fibreni. The red swamp crayfish can reduce the aquatic vegetation (Gherardi, 2006) and then compromise both feeding and breeding areas of the endemic trout.

We never observed indigenous and non-indigenous crayfish in syntopy, although we noted that $A$. pallipes had become extinct where NICs (in particular O. limosus) today occur (e.g., in Cicolani Mountains - Rieti). The replacement of $A$. pallipes by NICs may be due to crayfish plague, or in a few cases by competition (if the NICs are not carrying crayfish plague), or because $A$. pallipes had already been lost due to degradation of habitat, which was later colonised by NICs. Although indigenous and non-indigenous crayfish do not live in syntopy, there is a risk of transmission of crayfish plague between sites by the movement of birds, fish, and fishermen's equipment, carrying spores through the territory (Gherardi et al., 2002).

The introduction of NICs is a major threat to indigenous crayfish stock, but it appears that A. pallipes started to decrease in the 1970s. Although outbreaks of crayfish plague have occurred in Europe since 1860 (Vogt, 1999), the first record of NICs in central Italy was in 1994 (cf. Chiesa et al., 2006). Other problems, i.e. poaching, over-abstraction of water for public water supply or irrigation and urban pollution, can reduce the carrying capacity of A. pallipes, such as the case of the Viterbo watercourses which showed a low water quality (Scalici and Gibertini, 2006). These are major factors in the decline of $A$. pallipes, a species which is sensitive to environmental change and has low genetic diversity (Santucci et al., 1997). The occurrence of the white-clawed crayfish is actually limited to running waters with good environmental integrity (Scalici and Gibertini, 2005). It is absent from polluted or other 
degraded rivers, which is different from what has been observed by other authors who gave examples of the presence of $A$. pallipes in environments ranging from natural to slightly or moderately degraded (i.e. Demers et al., 2003; Füreder et al., 2003). Factors that have been shown to enhance the survival of $A$. pallipes are: habitat heterogeneity (Smith et al., 1996), diverse river morphology (Naura and Robinson, 1998; Brusconi et al., 2008), varied substrate especially stony substrate (Kirjavainen and Westman, 1999; Brusconi et al., 2008), good water quality, and lack of pollutants (Grandjean et al., 2003; Trouilhe et al., 2003; Scalici and Gibertini, 2005). To manage crayfish resources it is important to preserve both species and inland water habitats, and to avoid illegal fishing activities and further introductions of alien species. The no-go English areas (Holdich and Reeve, 1991), although criticized, may represent a useful solution, whether reinforced by valuable laws and good enforcement of regulations. In this sense an instrument such as the GIS may contribute to the identification of potentially areas for dispersion and colonization of nuisance species (Scalera, 2001). This means to increase the territorial control, although inside national boundaries there are no specific laws that regulate fish transport, especially of decapods.

It is widely acknowledged today that preventing the introduction of this invasive species is the only environmentally sound approach (Gollasch and Leppäkoski, 1999), and sometimes, eradication at an early stage of invasion may be effective with little or superficial knowledge of the population biology of the invasive species (Simberloff, 2003). But eradication may be sometimes expensive and its cost should be weighed against the benefits (Manchester and Bullock, 2000; Pimentel et al., 2005). In Latium, there is one of the few cases for invasive crayfish in which, due to the still confined distribution of O. limosus, A. leptodactylus, and C. destructor, eradication is still feasible and economically profitable. In the eradication context, also pheromones seem to be a potential instrument (Stebbing et al., 2004), although Peay and Hiley (2001) did not recommend pheromones. They mentioned that attractant pheromones might increase the efficiency of trapping. It also said "Trappings wholly ineffective as method of eradicating or even controlling a populations of crayfish". Stebbing et al. (2004) put effort into pheromone research and found that their extracts were no more attractive than food bait and worse, they were only attractive to males in the breeding season.

Finally, we think it is important to find out the distribution of the crayfish populations throughout Italy, to assess the risks to each populations and then to use the information to plan and implement management to protect and enhance populations of $A$. pallipes. We suggest that a national database of crayfish records ought to be constructed and be updated regularly in order to adopt future managing plans.

\section{ACKNOWLEDGEMENTS}

We are indebted to two anonymous referees, for their helpful suggestions towards improvement of this paper.

\section{REFERENCES}

Brusconi S., Renai B., Scalici M., Souty-Grosset C. and Gherardi F., 2008. Stock assessment in the threatened crayfish Austropotamobius italicus in Tuscany (Italy): implications for its conservation. Aquat. Conserv., 18, 1227-1239.

Capurro M., Galli L., Mori M., Salvidio S. and Arillo A., 2007. The signal crayfish, Pacifastacus leniusculus (Dana, 1852) [Crustacea: Decapoda: Astacidae], in the Brugneto Lake (Liguria, NW Italy). The beginning of the invasion of the River Po watershed? Aquat. Invasions, 2, 17-24.

Chiesa S., Scalici M. and Gibertini G., 2006. Occurrence of allochthonous freshwater crayfishes in Latium (Central Italy). Bull. Fr. Pêche Piscic., 380-381, 883-902.

Chiesa S., Celauro D., Scalici M., Monaco A., Scalisi M. and Gibertini G., 2008. II gambero rosso delle Louisiana Procambarus clarkii nella Riserva Naturale Regionale "Lago di Posta Fibreno": problematiche di gestione e priorità di azione per il futuro. Atti della prima giornata di studio "Tutela e conservazione dell'ecosistema acquatico Lago di Posta Fibreno area SIC/ZPS IT6050015”, Università degli Studi “La Sapienza”, Orto Botanico, 100-118. 
Demers A., Reynolds J.D. and Cioni A., 2003. Habitat preference of different size classes of Austropotamobius pallipes in an Irish river. Bull. Fr. Pêche Piscic., 370-371, 127-137.

Füreder L., Oberkofler B., Hanel R., Leiter J. and Thaler B., 2003. The freshwater crayfish Austropotamobius pallipes in South Tyrol: heritage species and bioindicator. Bull. Fr. Pêche Piscic., 370-371, 79-95.

Gherardi F., 2006. Crayfish invading Europe: the case study of Procambarus clarkii. Mar. Freshw. Behav. Physiol., 39, 175-191.

Gherardi F. and Holdich D.M., 1999. Crayfish as Europe as Alien Species - How to Make the Best of a Bad Situation?, A.A. Balkema, Rotterdam, 235 p.

Gherardi F., Baldaccini G.N., Ercolini P., Barbaresi S., De Luise G., Mazzoni D. and Mori M., 1999. The situation in Italy. In: Gherardi F. and Holdich D.M. (eds.), Crayfish in Europe as Alien Species - How to make the best of a bad situation?, A.A. Balkema, Rotterdam, 107-128.

Gherardi F., Smietana P. and Laurent P., 2002. Interactions between non-indigenous and indigenous crayfish species. Bull. Fr. Pêche Piscic., 367, 899-907.

Gherardi F., Aquiloni L., Tricarico E. and Morpurgo M., 2008a. Süsswasserkrebse In Italien. In: Füreder L. (ed.), Flusskrebse: Biologie - Ökologie - Gefährdung: Veröffentlichung des Naturmuseums Südtirol $N^{\circ}$ 6, Folio Verlag, Wien-Bozen, 53-65.

Gherardi F., Bertolino S., Bodon M., Casellato S., Cianfanelli S., Ferraguti M., Lori E., Mura G., Nocita A., Riccardi N., Rossetti G., Rota E., Scalera R., Zerunian S. and Tricarico E., 2008b. Animal xenodiversity in Italian inland waters: distribution, modes of arrival, and pathways. Biol. Invasions, 10, 435-454.

Gollasch S. and Leppäkoski E., 1999. Initial risk assessment of alien species in Nordic coastal waters. Available at the Nordic Council of Ministers, Copenhagen.

Grandjean F., Momon J. and Bramard M., 2003. Biological water quality assessment of the white-clawed habitat based on macroinvertebrate communities: usefulness for its conservation. Bull. Fr. Pêche Piscic., 370-371, 115-125.

Holdich D.M. and Reeve I.D., 1991. Distribution of the freshwater crayfish in the British Isles, with particular reference to crayfish plague, alien introduction and water quality. Aquat. Conserv., 4, 139-158.

Huner J.V., 2002. Procambarus. In: Holdich D.M. (ed.), Biology of Freshwater Crayfish, Blackwell, Oxford, 541-584.

Kirjavainen J. and Westman K., 1999. Natural history and development of the introduced signal crayfish, Pacifastacus leniusculus, in a small, isolated Finnish lake, from 1968 to 1993. Aquat. Living Resour., 12, 387-401.

Lodge D.M., Taylor C.A., Holdich D.M. and Skurdal J., 2000. Nonindigenous crayfishes threaten North American freshwater biodiversity: lessons from Europe. Fish., 25, 7-20.

Manchester S.J. and Bullock J.M., 2000. The impacts of nonnative species on UK biodiversity and the effectiveness of control. J. Appl. Ecol., 37, 845-864.

Mancini A., 1986. Astacicoltura - Allevamento e pesca dei gamberi d'acqua dolce, Edagricole, Bologna, $180 \mathrm{p}$.

Naura M. and Robinson M., 1998. Principles of using River Habitat Survey to predict the distribution of aquatic species: an example applied to the native white-clawed crayfish Austropotamobius pallipes. Aquat. Conserv. , 8, 515-527.

Peay S. and Hiley P.D., 2001. Eradication of Alien Crayfish. Phase II. Environment Agency Technical Report W1-037/TR1, Environment Agency, Bristol, 118 p.

Pimentel D., Zuniga R. and Morrison D., 2005. Update on the environmental and economic costs associated with alien invasive species in the United States. Ecol. Econ., 52, 273-288.

Santucci F., laconelli M., Andreani P., Cianchi R., Nascetti G. and Bullini L., 1997. Allozyme diversity of European freshwater crayfish of the genus Austropotamobius. Bull. Fr. Pêche Piscic., 347, 663-676.

Scalera R., 2001. Invasioni biologiche. Le introduzioni di vertebrati in Italia: un problema tra conservazione e globalizzazione, Ministero delle Politiche Agricole e Forestali, Corpo Forestale dello Stato, Roma, $368 \mathrm{p}$.

Scalici M. and Gibertini G., 2005. Can Austropotamobius italicus meridionalis be used as a monitoring instrument in Central Italy? Preliminary observations. Bull. Fr. Pêche Piscic., 376-377, 613-625. 
Scalici M. and Gibertini G., 2006. Distribuzione di Austropotamobius italicus nel Lazio (Italia centrale), Pubblicazione S.It.E. XV Congresso Nazionale - Società Italiana di Ecologia, Torino, 12-13/09/2005, 105-110.

Scalici M., Chiesa S. and Gibertini G., 2006. Austropotamobius italicus contraction and allochthonous freshwater crayfish expansion in Latium. J. Freshw. Biol. Quad. ETP, 34, 341-344.

Scalici M., Chiesa S., Gherardi F., Ruffini M., Gibertini G. and Nonnis Marzano F., 2009a. The new alien threat for the Italian continental waters from the crayfish gang: the turn of the invasive yabby Cherax destructor Clark, 1936. Hydrobiologia, 632, 341-345.

Scalici M., Chiesa S., Scuderi S., Celauro D. and Gibertini G., 2009b. Population structure and dynamics of Procambarus clarkii (Girard, 1852) in a Mediterranean brackish wetland (Central Italy). Biol. Invasions, DOI: 10.1007/s10530-009-9557-6.

Simberloff D., 2003. How much information on population biology is needed to manage introduced species? Conserv. Biol., 17, 83-92.

Smith G.R.T., Learner M.A., Slater F.M. and Foster J., 1996. Habitats features important for the conservation of the native crayfish Austropotamobius pallipes in Britain. Biol. Conserv., 75, 239-246.

Souty-Grosset C., Holdich D.M., Noël P.Y., Reynolds J.D. and Haffner P., 2006. Atlas of Crayfish in Europe, Muséum national d'Histoire naturelle, Paris, $187 \mathrm{p}$.

Stebbing P.D., Watson G.J., Bentley M.G., Fraser D., Jennings R., Rushton S.P. and Sibley P.J., 2004. Evaluation of the capacity of pheromones for control of invasive non-native crayfish, English Nature Research Reports, Peterborough, $38 \mathrm{p}$.

Trouilhe M.C., Ricard F., Parinet B., Grandjean F. and Souty-Grosset C., 2003. Management of the whiteclawed crayfish (Austropotamobius pallipes) in Western France: abiotic and biotic factors study. Bull. Fr. Pêche Piscic., 370-371, 97-114.

Vinciguerra V., 1898. I gamberi d'acqua dolce in Italia. Atti della Commissione Consultiva per la Pesca, Annali di Agricoltura, 219, 3-25.

Vogt G., 1999. Diseases of European freshwater crayfish, with particular emphasis on interspecific transmission of pathogens. In: Gherardi F. and Holdich D.M. (eds.), Crayfish in Europe as alien species How to make the best of a bad situation?, A.A. Balkema, Rotterdam, 87-103. 